\title{
THE CORRELATION BETWEEN THE STUDENTS' VOCABULARY MASTERY AND THEIR WRITING SKILL OF THE TENTH GRADE STUDENTS OF \\ SMA NEGERI 1 KERAJAAN IN THE ACADEMIC YEAR OF 2020/2021
}

\author{
Anggraeni Etrika. U. Limbong, Viator Lumban Raja, Anna Stasya Prima Sari \\ Catholic University of Saint Thomas \\ Email : viator_lumbanraja@ust.ac.id
}

\begin{abstract}
Writing is one of the important skills in learning English that should be acquired by the students. And also it is one of the most difficult skills to the students to $b$ acquired in the learning English. One of the reasons is the lack of students' in vocabulary mastery. That is why this research was conducted in order to find out the correlation between students' vocabulary mastery and their writing skill at the tenth grade students of SMA Negeri 1 Kerajaan in the Academic Year of 2020/2021 which is consist of four classes. The writer took 53 students as the sample of this research by whose students numbers are odd randomly. The instrument in collecting data is the test. The tests were used to collect the data of the students' vocabulary mastery and their writing skill. The techniques which were used to analyze the data are normality test, Linear Regression Analysis Statistic and Pearson Product Moment by using Statistical Product and Service Solution (SPSS). The result of hypothesis test showed that the coefficient of correlation is 0,638 at the significant level $0,5 \%$. Since the $r_{\text {count }}$ is higher than $r_{\text {table }}(0,638>0,279)$ it means that $H_{o}$ is rejected. It can be concludedthat there is a significant correlation between students' vocabulary mastery and their writing skill at the tenth grade students of SMA Negeri 1 Kerajaan in the Academic Year of 2020//2021.
\end{abstract}

Keywords: Correlation, vocabulary mastery and writing skill.

\section{INTRODUCTION}

Writing is a process of sharing information, messages, ideas, or thoughts in grammatically correct sentences. Writing as one of four language skills is considered adifficult skill as well difficult subject. It is because students have to produce a text by using English correctly according to grammatical correctness. The students have to write what they think in their mind and state it on a paper by using correct produce. Writing also need series practices to develop this skill. It cannot be achieved in one time learning only. Harmer (2004:31) states that writing (as one of the four skill of listening, speaking, reading and writing) has always formed part of the syllabus in the teaching English. Writing is one of the skills in the English language that is learnt by the students in the school, while the vocabulary is supporting components. Without vocabulary, there is not much to write down. Thus, the writer tried to relate both of them. The writer also wanted to determine the level of students' ability to learn the vocabulary and writing. Then the writer searched the relationship between the both.

In learning English, we know that vocabulary is a language aspect which should be mastered by the students to understand whole English skills, reading, speaking, listening, and writing. Learners of a foreign language will speak fluently 
and clearly, if they can understand what they read or hear and they will write easily, if they already had enough vocabulary. An understanding of vocabulary will aid the students in understanding the meaning of the words in their reading. Similarly in speaking, they cannot speak fluently if they have only few vocabulary words. By good vocabulary mastery they can communicate their ideas more fluently with other people. Futhermore, in listeningthe students can understand what the speaker says if they know lots of words. When the people are listening to English words they can absolutely understand about the words said by someone if they have good vocabulary mastery. In addition, vocabulary is very essential in writing. A good writer needs a wide range of vocabulary to strengthen the clarity and accuracy of their writing

From the above explanation, the writer is interested in conducting a research entitled "The Correlation Between Students Vocabulary Mastery and Their Writing Skill at SMA Negeri 1 Kerajaan in the Academic Year of 2020/2021". This study focuses on the tenth grade students who have studied about kinds of writing, such as narrative, recount, descriptive, and explanatory. They will be asked to write a recount text which is divided to three themes such as best experience, unforgetable moment or their very best moment in their life. and then given a vocabulary test of daily life. Later, it will be investigated whether there is a significant correlation between the two.

\section{REVIEW OF LITERATURE Writing}

Most people have certain ways to convey and deliver their message in communication. One of the ways is writing. There are a lot of definitions of writing according to the experts. Harmer (2001:79) states that writing is a form of communication to deliver through or to express feeling through written form. It means that writing is productive skills that express feeling through written communication.

Futhermore, Nunan (2003:88) states that the process of thinking to invent ideas, thinking about how to express into good writing, and arranging the ideas into statement and paragraph clearly. It indicates that the students are expected to explore the ideas and arranging into good paragraph.

Based on the defenition, the writer concludes that writing is a process of communicating a message to a reader for a purpose and someone's ability to communicate his information, ideas, and feelings to someone in the form of written.

\section{The Process in Writing}

Langan (2005) divides writing process into four types, is explained below:

Prewriting

In prewriting there are five types of techniques that will help students to think about developing a topic and words on paper. These techniques help students to write in the first time they start to write something.

\section{Free writing technique}

Free writing means jotting down in rough sentence or phrase everything that comes to mind about a possible topic. In this time, students can write anything in 
their mind without worried about the mistake, students can focus on discovering what they want to say about subject.

\section{Questioning technique}

In questioning, students generate ideas and details by asking question about their subject. By asking the question, students can get the ideas and think about the subject. The question such as: Why, Where, When, Who and How.

3.Making a list

Making a list is also known as brainstorming. In this technique students can collect ideas and details that relate to their subject. Student can pile ideas without trying to sort major detail. The purpose is just to make a list of everything about their subject that occurs to them.

\section{Clustering or Mapping}

Clustering is another strategy that can be used to generate material for a paper.This method is helpful for people who like to do their thinking in a visual way. In this technique students can use lines, circle or arrows to show the relationship between the ideas and details that were they made.

5.Preparing a starch outline

A starch outline is an excellent sequel to the first four pre writing technique. In a starch outline, students think carefully about the point they are making, the suppllorting items, arrange those items. The starch outline is a plan to help students to achieve a unified, supported and well organized.

\section{Writing a first draft}

In this time, students should be prepared to put in additional thoughts and details that did not emerge during prewriting. They can write and ignore about the grammar, punctuation or spelling.

\section{Revising}

Revising means rewrite a paper, building on what has already been done, in order to make students' idea clearly. Revising is as much stage in the writing process as prewriting, outlining and doing the first draft. In revising, students can arrange their writing to put things in the right place. Finally, after they do all the things, students can write in paper. There are three stagesto revising process: revising content, revising sentences and editing.

\section{Editing}

After students have revised their paper for content and style, they are ready to check errors in grammar, punctuation and spelling. The writing is better after finished thisstep.

\section{Publishing}

Publishing simply involves distributing your work in its finished format. For a freelance writer, this is generally interpreted as distributing the project to the client, sending off a query letter, or submitting a book proposal. While the goal is to have your work met with enthusiastic reviews, rejection is often one of the components of the writing process. 


\section{The Component of Writing}

Writing in English within an academic context requires some criteria of acceptability relative to different aspects of writing which include organization, vocabulary, language use, punctuation, accurate capitalization and paragraphing. According to Starkey (2004)an effective piece of writing is the one that is organized, clear, and coherent, with accurate language and effective word choice

a. Organization

It means how the students organize their idea. Whether each paragraph is organize well or not. The organization of the text is fluent in expressing, reveal clearly ideas, good organization, logic sequence, and cohesive.

b. Content

The content refers to the topic and its explanation, discussion, evaluation, and conclusion. It should be clear, specific, and relevant. The good content had to fulfill the criteria such as full of information, substantive make a clear thesis development and relevant with the problem.

c. Language

The students use effective complex sentence construction and make only few faults in the using of grammar.

d. Vocabulary

When the students have to choose the correct words as it is function and master informing words.

e. Mechanic

Paragraph is a combination of some sentences which needs good spelling and punctuation. If the use of punctuation is not appropriate, the paragraph will be unreadable. So the students should be mastered in writing good paragraph.

\section{The Problem of Writing}

According to Nurgiyantoro (2001:298-299), there are some problems faced by students in learning writing, is explained below:

a. Organizing Idea

The students usually face problem in writing process such as how to organize the idea into sentences. In writing composition, students will put their ideas and thoughts to be developed become a good written. It will be better if we start the writing process by choosing theme first before we write the composition. After that we can make an outline to help us in arranging the sentences or paragraphs.

\section{b. Lack of Vocabulary}

Vocabularies become complex problem especially in writing. Lack of vocabulary makes students often write uncommunicative sentence. Besides that, they often choose incorrect words in their composition.

c. Grammar Accuracy

Grammar becomes very important aspect in writing. A draft will be said a good draft if grammar which is used is correct. 


\section{Vocabulary}

Vocabulary is the core of language, and it is also the basics of communication. Flower (2000:2) states that vocabulary is very important part of learning English. It means that by mastering the vocabulary, students can communicate an undestand English learning well. Hiebert and Kamil (2005:3) state that vocabulary is the knowledge meanings of words uthermore, Langan (1993:43.) states, "A good vocabulary is a vital part of effective communication". It means that vocabulary will make you became a good writer, speaker, listener, and readers. It helps you to communicate fluently and clearly.

\section{The Kinds of Vocabulary}

Based on Hycraft (in Hatch and Brown, 1995:44), vocabulary mastery is divided into two kinds, is explained below:

1. Active vocabulary consist of those words over which one usually use in the time of speaking and writing.

2. Passive vocabulary is made up the words that an individual recognizesbut rarely uses in when speaking and writing.

Meanwhile, Thornbury (2002:22) also divides vocabulary mastery intotwo kinds, is explained below:

1. Receptive vocabulary is words that learners recognize and nderstand when they are used in context, but which they cannot produce. It is vocabulary that learners recognize when reading a text but do not use when speaking and writing.

2. Productive vocabulary is the words that the learners understand and can pronounce and use constructively when speaking and writing. It involves what is needed for receptive vocabulary and can be addressed as an active process, because the learners can produce the words to express their thoughts to others.

Every expert in every book is different in classifying the kinds of vocabulary, because every person has different way in showing and telling their opinions and ideas. Event the classifications of the kinds of vocabulary mastery that they have made are different, but the point is the same. Generally the kinds of vocabulary, are divided into two aspect e.g receptive or passive vocabulary and productive and active vocabulary. Receptive vocabulary are used when the time of listening and reading and perceptive vocabulary are used when the time of speaking and writing.

\section{Lexical Relation}

The characterizing of the word meaning not in terms of its component features, but in terms of its relationship to other word is treated as the analysis of lexical relation. The types of lexical relations which are usually appealed to can be briefly defined to two kinds, is explained below:

\section{a. Synonym}

It is a word which has the same or nearly the same meaning as other. These synonyms are two or more forms with very closely related meaning, which are often but not always, intersubstitutable in sentence. Examples of synonym are the pairs: applaud-cheer, brief-short, bold-brave. 


\section{b. Antonym}

It is a word which is opposite in meaning to other word. Two forms opposite meaning are called antonym. Example of antonym are the pairs: boy:girl, off:on, night:day, true:false, and etc.

\section{The Importance of Vocabulary}

Vocabulary is very important when learning a foreign language, because it is the basic knowledge to achieve comprehension in learning and using the language. For this reason, people who want to able to communicate in a certain language have to master the langauge vocabulary for the first time. If learners spend most of their time studying grammar, their English will not improve much. They will see most improvement if they learn more words and expression. They may use very little grammar, but they can say almost anything with words. Students weak with vocabularies tend to decline academically, while students with stronger vocabularies tend to learn faster.

Vocabulary is central to English language teaching because without sufficient vocabulary mastery students cannot understand others to express their own ideas. Nunan (1998:72) says, "The development of a rich vocabulary is an important element in acquisition of a second language". It is important for a learner to master the vocabulary mastery of the target language because it is an essential part of communication. Also, when people do not understand the grammar in the English language they can still communicate with a native speaker if they have a lot of vocabulary mastery.

\section{Hypothesis}

A hypothesis is a tentative answer to the problem of the study. If $\mathrm{H}_{\mathrm{a}}$ is accepted, $\mathrm{H}_{0}$ is rejected, on the other hand if $\mathrm{H}_{\mathrm{a}}$ is rejected, $\mathrm{H}_{0}$ is accepted. If $\mathrm{H}_{\mathrm{a}}$ is accepted, it means the improvement of students' vocabularymastery will be followed by the improvement of their writing skill. But if $\mathrm{H}_{\mathrm{a}}$ is rejected, it means if students have got high vocabulary mastery, it does not automatically indicate that they got high writing skill.

\section{RESEARCH METHOD \\ The Research Design}

This research belongs to quantitative research. Quantitative research is intended to determine the relationship between two variables; they are independent variable and dependent variable. This study would use descriptive quantitative method. Kumar (2005:19) states, "Quantitative research method falls under the board heading research. Corelational research is a quantitative method designed to show the relationship between two variables". It means this research will show the relationship of two variables. According to Fraenkel and Wallen (2015:31) corelational research is also sometimes referred to the form of descriptive research because it describes an existing relationship between two variables. The design of this research can be shown as the following: 


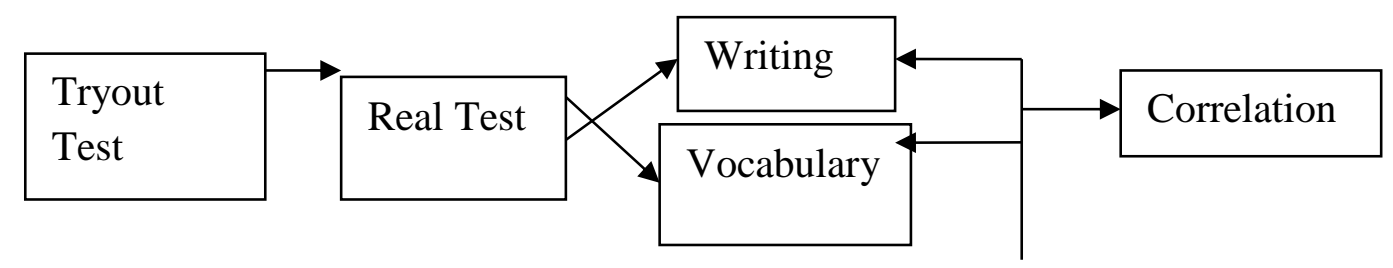

First of all, try out is carried out for vocabulary test in order to determine the validity and reliabilty of the test. Then, the real test of writing and vocabulary is administered. The result of both of the test will be processed to find out the correlation between the two.

There are three possible results of a correlation study: a positive correlation, a negative correlation, and no correlation. The correlation coefficient is a measure of correlation strength and can range from -1.00 to +1.00 . perfect positive correlation would result in a score of +1 ; perfect negative correlation would result in -1 ( Nunan 2012:39).

1. Positive correlation

Positive correlation indicates that both of variables improve or decrease at the same time. A correlation coefficient close to +1.00 (it indicataes a strong positive correlation).

2. Negative correlation

Negative correlation indicates that as the amount of the one variable improves, the other decreases. A correlation coefficient close to -1.00 (it indicates a strong negative correlation).

3. No correlation

No corelation indicates that there is no relationship between two variables. A correlation coefficient is 0 (it indicates no correlation).

In this research, there are two variables, that is independent variable $(\mathrm{X})$ and dependent variable (Y) namely:

a. Independet variable

Independent variable in this research is the vocabulary mastery of the tenth grade students of SMA Negeri 1 Kerajaan(X).

b. Dependent variable

Dependent variable in this research is writing skill of the tenth grade students of SMA Negeri 1 Kerajaan (Y).

Negeri 1 Kerajaan (Y).

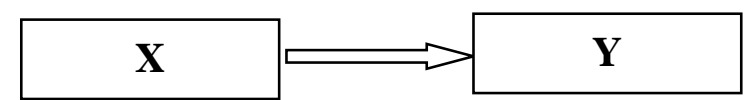

Figure 2. Diagram of the Relationship between Students' Vocabulary Mastery (X) and Writing Skill (Y)

In which:

$\mathrm{X}$
$\mathrm{Y}$
$\mathrm{C}$




\section{The Place and Time of the Research}

The writer conducted the study to the tenth grade students of SMA Negeri 1 Kerajaan which is located at Jl. Mbinanga Sitellu Kecamatan Kerajaan Kabupaten Pakpak Bharat. It started in September 2020 in the Academic Year 2020/2021. Based on the writer's knowledge there has never been any research about the correlation between vocabulary mastery and writing skill in this school.

The students' score ranges from 0-100 for vocabulary mastery which is used as follows:

$$
S=\frac{R}{N} \times 100
$$

Where:

$$
\begin{array}{ll}
\mathrm{S} & =\text { the score of the test } \\
\mathrm{R} & =\text { the total of the right answer } \\
\mathrm{N} & =\text { the total items } \\
100 & =\text { standard }
\end{array}
$$

a. Test of writing skill

To measure students' competence in writing skill, the writer employed a composition test in which they are required to write a composition about their best experience, unforgetable moment or their best experience in their life.

The students' ability in writing skill can be measured by using the following assessment below:

\begin{tabular}{|c|l|l|l|l|l|}
\hline \multirow{2}{*}{ NO } & Aspect Assessed & \multicolumn{4}{|c|}{ Score } \\
\cline { 3 - 6 } & & $\mathbf{1}$ & $\mathbf{2}$ & $\mathbf{3}$ & $\mathbf{4}$ \\
\hline 1 & Content & & & & \\
\hline 2 & Organization & & & & \\
\hline & a. Orientation & & & & \\
\hline & b. Events & & & \\
\hline & c. Re-orientation & & & & \\
\hline 3 & Vocabulary & & & & \\
\hline 4 & Grammatical Features & & & & \\
\hline & a. Temporal Sequence & & & & \\
\hline & b. Specific participant & & & & \\
\hline & c. Action verb & & & & \\
\hline 5 & Spelling and Punctuation & & & \\
\hline Total & & & & \\
\hline Maximum Score & & & \\
\hline
\end{tabular}

Explanation of Score:

$1=$ incompetent

$2=$ competent enough

$3=$ competent

$4=$ very competent 
Final Score $=\frac{\text { Total Score }}{\text { MaximumScore }} \times 80$

\section{Validity and Reliability of the Instruments}

Before administering the test to the students, the writer made a try-out test in order to find out the validity and reliability of the test.

\section{a. Validity}

Valid means that the instrument can be used to measure what it should measure. Valid instruments indicates high validity. Conversely a less valid instrument means having low validity. Arikunto (2002:145) says, "An instrument can be valid if it can reflect what is being measured".

The formula that used is:

where:

$$
R x y=\frac{N \sum x y-\left(\sum x\right)\left(\sum y\right.}{\sqrt{\left(N \sum X 2-\sum X\right) 2\left(N \sum Y 2-\left(\sum Y 2-\left(\sum Y\right) 2\right.\right.}}
$$

$\mathrm{R}_{\mathrm{xy}} \quad=$ The co relational coefficient between vocabulary mastery and writing skill

$\mathrm{N} \quad=$ The nuber of respondents

$\mathrm{X}=$ The students score in vocabulary

$\mathrm{Y} \quad=$ The students score in writing

$\sum X \quad=$ The sum of vocabulary mastery

$\sum Y=$ The sum of writing skill

$\sum X^{2} \quad=$ The sum of squares of vocabulary mastery

$\sum Y^{2} \quad=$ The sum of squares writing skill

$\left(\sum X\right)^{2}=$ The squares of sum vocabulary mastery

$\left(\sum Y\right)^{2}=$ The squares of the sum of writing skill

$\sum X Y=$ Total number of vocabulary mastery and writing skill

To find out if the tests were valid or invalid, it depends on the value of $R_{x y}$ and $R_{\text {table. If }} R_{x y}>$ than $R_{\text {table }}$ the test is valid, and if $R_{x y}<$ than $R_{\text {table }}$ the test is invalid. b. Reliabilty

According to Nunan (1998:14), reliability refers to be consistency and the result obtained from a piece of reserach. To find out the realibilty of the test, the writer used the Alpha Combach formula:

The formula is:

$$
r 11=\frac{k}{k-1} \times\left(\frac{v t-\sum p q}{v t}\right)
$$

Where:

$\mathrm{r}_{11}=$ the value of realibilty

$\sum p q^{2}=$ the number of variance score per each score

$\mathrm{vt} \quad=$ total number

$\mathrm{k} \quad=$ the question

In calculating the realibilty of the test, the writer would count the value of the variance of each question. Then the writer would find out the total variance of all the questions. After that, the writer will count the value of $r_{11}$ and $r_{\text {table. To find }}$ out if the tests were reliable or not, it depends on the value of $r_{11}$ and $r_{\text {tableto indicate }}$ if the test was reliable or not. 


\section{The Technique of Analyzing Data}

As stated previously, this research tended to determine the correlation between independent variable (vocabulary mastery) and dependent variable (writing skill). In order to achieve this, the relationship between two variables must be established. The writer tested the hypothesis using Product Moment and Linear Regression formula. Borg and Gall ( in Arikunto, 2002:251) say, "Product moment is used to describe the strength of the relationship between two variables, while Multiple Linear Regression is used to describe the strength on independent variable and dependent variables". In this research, the writer tended to use the computerized calculation by utilizing Statistical Product and Service Solution (SPSS).

The procedures of analyzing data are:

1. The writer gave try out to the students at SMA Negeri 1 Tinada to validate the test.

2. After validating the data then the writer conducted a real research at SMA Negeri 1 Kerajaan.

3. The writer gave a vocabulary test to the students and continued the writing test.

4. After collecting the data the writer analyzed them by using SPSS.

\section{Normality Test}

Normality test is one of the test prerequisite before the entering linear regression analysis, that is to know wheter the dependent variables are normally distributed or not. To check the normally test of dependent variable; it can be done by using Kolmogrov ( uji K-S) Technique in SPSS. The normality of the test cn be seen from $p$ ( significance ) on Lilliefors test. If $p$ value is greater than 0,05 it tells that the distribution of the data is normal.

\section{Hypothesis Test}

To test the hypothesis, the writer used the simple co relational technique using the product moment formula, computerize by using SPSS. The value of $r_{x y}$ is then compared with product momen table $\left(r_{1}\right)$ at the level significance of $5 \%$ and $\mathrm{N}=$ the number of respondent. If $\mathrm{r}_{\mathrm{xy}}$ is greater than $\mathrm{r}_{t}$ it means that Hois rejected. On the other hand, if $r_{x y}$ is lower than $r_{\text {table }}$, it means that $\mathrm{H}_{0}$ is accepted. That means there is no correlation between vocabulary mastery and writing skill of the students. How strong the correlation is will be indicated by the coefficient of $r_{x y}$.

\section{The Population and Sample}

To find out the correlation between variable $\mathrm{X}$ and $\mathrm{Y}$ we needed to limit the population and sample. Population and sample of this study were elaborated as follows: the population is the whole number of object of the research, in which the sample is taken. In this study, the population is all the tenth grade students of SMA Negeri 1 Kerajaan in the Academic Year 2020/2021 that consist of four classes, namely X-IPA 1 class consisting of 34 students, X IPA 2 classs consising 35 students, X IPS 1 class consisting 36 students and X IPS 2 class consisting 35 students. The whole numbers of students are 140 students. The sample of this research are ten students of each class randomly taken. From class X-IPA 1 students with odd number in the presence list are taken as a sample, from class XIPA2 students with even number,from class X-IPS 1 students with odd number and 
from class XIPS 2 with even number again. Thus, the total number of the sample is 40 students.

\section{The Instrument of Collecting Data}

In order to get some data that are needed to support this research, the writer applied the following steps as follows:

\section{Try Out}

The test must be valid and reliable. Try out of the tests were conducted to identify how valuable and effective the tests are before they will be used to collect data of the research and identify whether the test can be administered or not. It could be seen from the result of reliability and validity of the test. Try out of the test was conducted in September. This test was given to the tenth grade of SMA Negeri 1 Tinada. The try out was prepared in form of multiple choice question in 40 items of vocabulary mastery test, the test item is evaluated to get good items that were tested in the test.

The Test

Two tests are used as instruments to collect the data:

a. Test of Vocabulary Mastery

The test of vocabulary mastery is intended to collect the data about students' mastery on vocabulary. The test is objective test in the form of multiple-choice consisting of 20 items from 40 items in try out.

There are four option: $a, b, c, d$ in each question.

In analyzing the data, the writer used score of each variable and to know the scores' category of students' vocabulary mastery that is based on the table below ( Departemen Pendidikan dan Kebudayaan 2004:10 ).

Table 2. The Scores' Categories of Students' Vocabulary Mastery

\begin{tabular}{|c|c|c|}
\hline Scores & Grade & Classifications \\
\hline $86-100$ & A & Excellent \\
\hline $66-85$ & B & Good \\
\hline $46-65$ & C & Fair \\
\hline $26-45$ & D & Pure \\
\hline Under 25 & E & Failed \\
\hline
\end{tabular}

\section{DATA ANALYSIS AND DISCUSSION \\ Data Analysis}

As it had been mentioned in the previous chapter, the data of this reserach were taken from the result student's vocabulary mastery and their writing test. Vocabulary mastery is indicated as variable $\mathrm{X}$, while writing skill is indicated as variable $\mathrm{Y}$.

There are two data in this research, there are vocabulary mastery score and writing skill score. In conducting this research, the writer took two schools. The first school isSMA Negeri 1 TINADA where the writer carried out try out test in order to know the validity and reliability of the test. Validity refers to the content of the test wheter it really measures what it is intended to measure. In this case, the writer refers to the curriculum used in that school. And the reliability refers to the consistency of the scores when it is administered in another time. The try out test of vocabulary was carried out at SMA Negeri 1 TINADA in September $11^{\text {th }} 2020$ 
to the tenth grade students. This tryout test was carried out after the writer got the permission from the principal of the school.the writer sets 1 our to finish the test.

\section{Testing Reliability and Validity of Vocabulary Mastery Test} followed:

There are two kinds of testing test. The two kinds of the test are stated as

\section{Testing Reliability of Vocabulary Mastery Test}

To find out the reliability of the test, the writer used the Alpha Combach formula. After counting the value of the variance of each questions, the writer found out the total variance of all questions. The total variance of the entire questions is 6.71. then, the writer counted the value of $r_{11}$ and $r_{\text {tabel. }}$. Afterthe writer counted the $r_{11}$, the writer found that $r_{11}$ higher than $r_{\text {tabel. }}$. It means the question are reliable, the result shows $0,888>0,374$.

\section{Testing validity of Vocabulary Mastery}

The writer used Statistical Package for Sosial Science (SPSS) to obtain the validity of the try out vocabulary mastery. The respondent of the try out was 28 students and the value of $r_{\text {table }}$ is 0,374 ..

After giving the try out to the students, the writer calculated the validity of the vocabulary mastery by SPSS, it was found that from the 40 questions that had been given to the students by the writer, there are 25 question are valid namely question $1,2,4,5,6,7,8,9,10,11,17,21,22,23,25,26,27,29,32,33,34,35,36,37,38$. The writer only took 20 questions from the 25 question that are valid because 5 questions out of 25 valid questions are very easy to test. That is why the writer only took 20 questions out of 25 valid questions during the try out. The calculation of the reliability also showed that the try out was reliable, it could be seen form the value of $r_{\text {count }}$ is higher than $r_{\text {table. }}$.

\section{The Result of the Students' Vocabulary Mastery and Writing Skill Score}

The real test was carried out in September $21^{\text {st }}$, 2020 to the tenth grade students of SMA Negeri 1 Kerajaan that consist of four classes. The writer conducted the vocabulary mastery test and writing skill test. The write entered the classes and gave the test to the students. The sample that would be taken are odd number students and even number students from the class attendance list. The number of the students is 53 . Then the writer gave the students vocabulary mastery test that consist 20 items multiple choice and the writer gave the rules and tell about the topic for writing skill test to the students which is about their best experience, unforgetable moment or their best moment in their life and students choose one of the story from their best experience. The writer sets one hour to finish the test.

The result shows that the highest score of vocabulary mastery is 65 and the lowest score is 15 . While in writing skill, the highest score is 65 and the lowest is 5. The standard deviation in vocabulary mastery is 11,4 and in writing skill is 17,15 .

The writer made a chart which showed how good students' achievement on vocabulary mastery and writing skill based students' scoring rubric. The scoring rubric of the students' vovabulary mastery and speaking skill were presented in table 4 . 
Table 3. The Scoring Rubric of Vocabulary Mastery

\begin{tabular}{|c|c|c|c|}
\hline Scores & Number of Students & Grade & Classifications \\
\hline $86-100$ & 0 & A & Excellent \\
\hline $66-85$ & 0 & B & Good \\
\hline $46-65$ & 9 & C & Fair \\
\hline $26-45$ & 30 & D & Pure \\
\hline Under 25 & 14 & E & Failed \\
\hline
\end{tabular}

From the table above it can bee seen that there is no students who got excellent and good score, 9 students who got fair score with range 46-65 in grade C, 30 students who got poor score with grade 26-45 in grade D, and 14 students who got failed with range under 25 in grade $\mathrm{E}$.

\section{Percentage of Vocabulary Mastery}

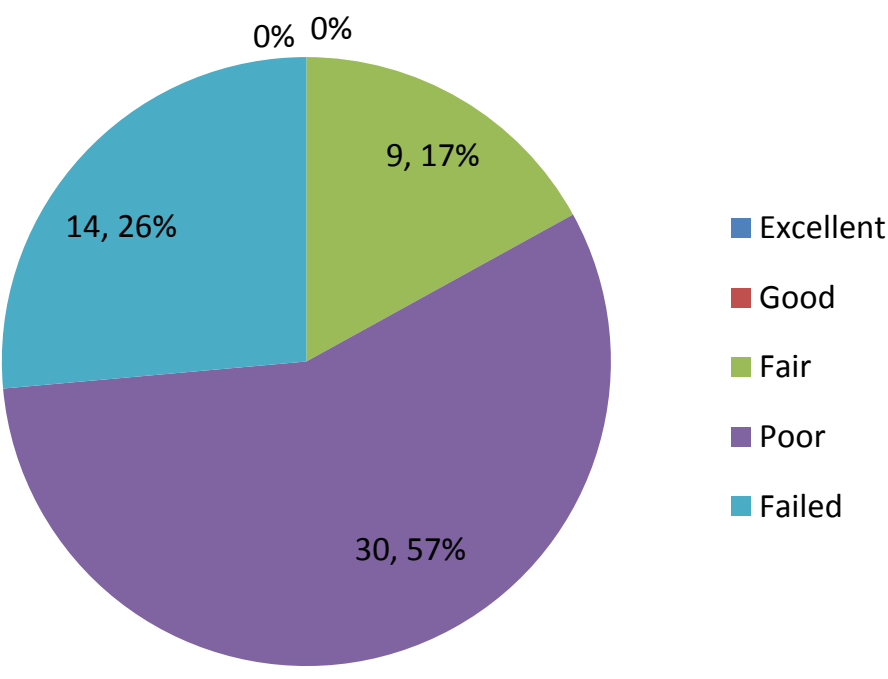

\section{Chart 1. Percentage of Vocabulary Mastery}

From the chart 4 . the writer concludes that vocabulary mastery at the tenth grade students of SMA Negeri 1 Kerajaan is in poor level. There is no students who got excellent and good score (0\%), 9 students who got fair score (17\%), 30 students who got poor score $(57 \%)$ and 14 students who got failed score $(26 \%)$.

Table 4. The Scoring Rubric of Writing Skill

\begin{tabular}{|c|c|c|c|}
\hline Scores & Number of Students & Grade & Classifications \\
\hline $86-100$ & 0 & A & Excellent \\
\hline $66-85$ & 0 & B & Good \\
\hline $46-65$ & 8 & C & Fair \\
\hline $26-45$ & 9 & D & Pure \\
\hline Under 25 & 36 & E & Failed \\
\hline
\end{tabular}


From the table above it can be seen that there are no students who got excellent and good score, 8 students who got fair score with range 46-65 in grade C, 9 students who got poor score with range $26-45$ in grade D and 36 students who got failed score with range under 25 in rade $\mathrm{E}$.

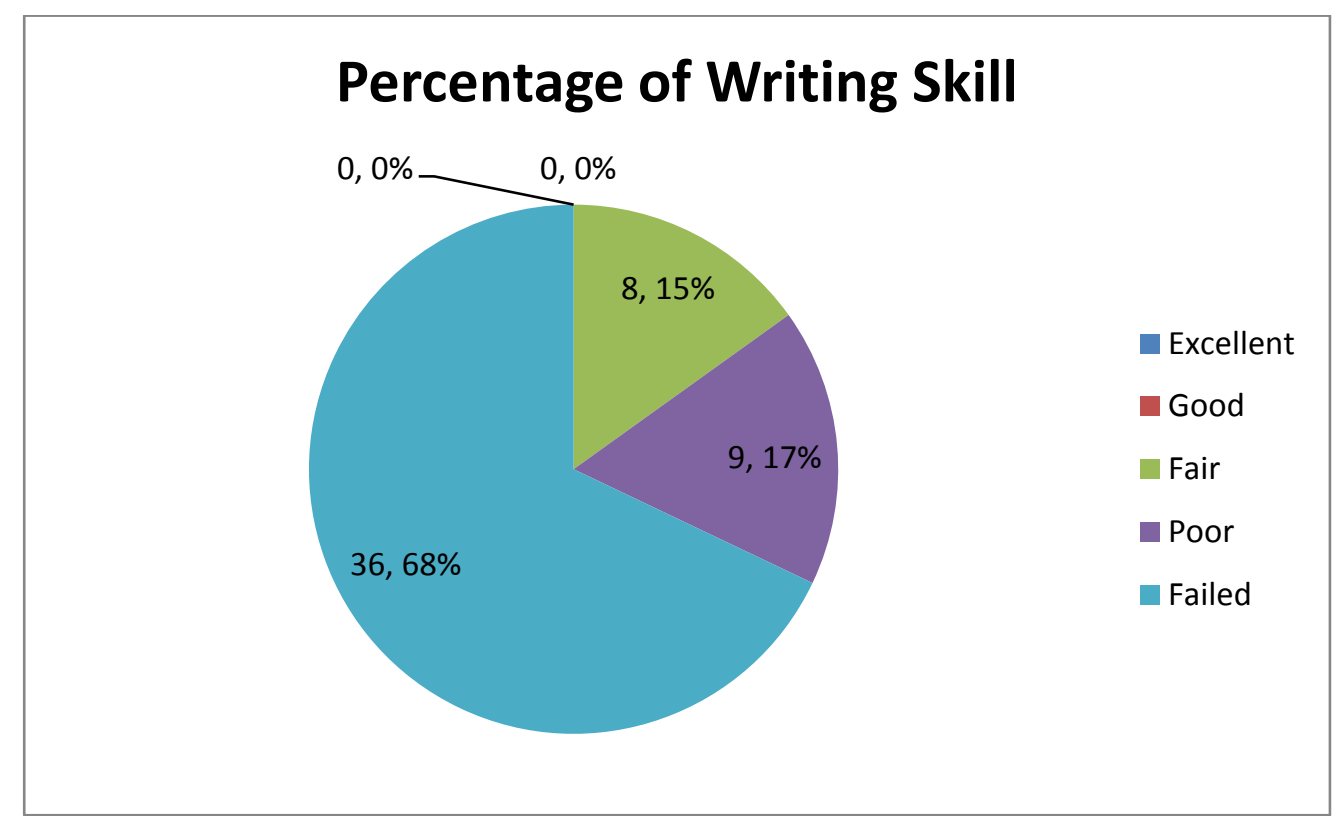

Chart 2. Percentage of Writing Skill

From the chart 2 the writer concludes that writing skill at the tenth grade students of SMA Negeri 1 Kerajaan is in poor level. There are no students who got excellent and good score, 8 students who got fair score (18\%), 9 students got poor score (17\%), and 36 students who got failed score $(68 \%)$.

Data Analysis

Data analysis presented the result of the research to determine if the students' vocabulary mastery and writing skill have a significant correlation. This data analysis concerns with the analysis of students' vocabulary mastery, analysis of the students' writing skill, and the correlation between the students' vocabulary mastery and their writing skill.

\section{Data Analysis of the Students' Vocabulary Mastery}

From the data of the students' vocabulary mastery, the writer analyzed the range, class, interval and standart deviation. Basedon the data, the result is presented as follows:

Table 5. The Frequency Cummulative of the Students' Vocabulary Mastery

\begin{tabular}{|c|c|c|}
\hline Interval & Frequency & Frequency Cummulative \\
\hline $7-13$ & 0 & 0 \\
\hline $14-20$ & 5 & 5 \\
\hline $21-27$ & 9 & 14 \\
\hline $28-34$ & 10 & 24 \\
\hline $35-41$ & 16 & 40 \\
\hline
\end{tabular}


KAIROS ELT JOURNAL, Vol. 2 Agustus 2020

Copyright@2020, ISSN: 2580-4278

\begin{tabular}{|c|c|c|}
\hline $42-49$ & 4 & 44 \\
\hline $50-56$ & 6 & 50 \\
\hline $57-63$ & 1 & 51 \\
\hline $64-70$ & 2 & 53 \\
\hline $71-77$ & 0 & 0 \\
\hline $78-84$ & 0 & 0 \\
\hline $85-91$ & 0 & 0 \\
\hline $91-98$ & 0 & 0 \\
\hline
\end{tabular}

The table above shows that there are no students who got score interval 713, 5 students who got score interval 14-20, 9 students who got score inteval 21-27, 10 students who got score interval 28-34,16 students who got score interval 35-41, 4 students who got score interval 42-49, 6 students who got score interval 50-56, 1 student who got score interval 57-63, and 2 students who got score interval 64-70.

\section{Data Analysis of the Students' Writing Skill}

From the data of the students' writing skill, the writer analyzed the range, class, interval, and standart deviation. Based on the data, the result are presented as follows: range $=85$, class $=7$, interval $=9$, mean $=18$, variance $=294,17$, standard deviation $=17,15$.

Table 6. The Frequency Cumulative of Students' Writing Skill

\begin{tabular}{|c|c|c|}
\hline Interval & Frequency & Frequency Cumulative \\
\hline $5-13$ & 34 & 34 \\
\hline $14-22$ & 2 & 36 \\
\hline $23-31$ & 8 & 44 \\
\hline $32-40$ & 2 & 46 \\
\hline $41-49$ & 0 & 46 \\
\hline $50-58$ & 5 & 51 \\
\hline $59-67$ & 2 & 53 \\
\hline $68-76$ & 0 & 0 \\
\hline $77-85$ & 0 & 0 \\
\hline $86-94$ & 0 & 0 \\
\hline
\end{tabular}

Thetable above shows that 34 students who got score interval $5-13,2$ student who got score interval $14-22,8$ students who got score interval $23-31$, 2 students who got score interval $32-40,5$ students who got score interval $50-$ 58,2 students who got students interval $59-67$.

\section{Data Analysis of the Correlation between Students' Vocabulary Mastery and Writing Skill}

In this research the writer used the Pearson Product Moment Formula to analyze the correlation between vocabulary mastery and writing skill. Variable X used to represent vocabulary mastery score and variable $\mathrm{Y}$ was used to represent writing skill score. From the data of the students' the writer analyzed $\sum X, \sum Y, \sum X^{2}$, 
$\sum Y^{2}, \sum X . Y$. based on the data, th result are presented as follows: $\sum X=1885$, $\sum Y=970, \sum X^{2}=73825, \sum Y^{2}=33050, \sum X . Y=41000$. The writer presented the correlation between vocabulary mastery and writing skill as follows:

Based on the table, the correlation between the two variables could be calculated by using Pearson Product Moment. The formula of Pearson Product is:

Where:

$$
\mathbf{R x y}=\frac{N \sum X Y-\left(\sum X\right)\left(\sum Y\right)}{\sqrt{\left.\left(N \sum X 2-\sum X\right) 2\right)\left(N \sum Y 2-\left(Y 2-\left(\sum Y\right) 2\right)\right.}}
$$

Rxy = The Correlation Coefficient between vocabulary mastery and their writing skill

$\mathrm{N}=$ The number of respondents

$\mathrm{X} \quad=$ The students' Score of vocabulary mastery

$\mathrm{Y} \quad=$ The students' score of writing skill

$\sum X \quad=$ The Sum of vocabulary mastery

$\sum Y \quad=$ The Sum of Writing Skill

$\sum X^{2}=$ The Sum of Squares of Vocabulary Mastery

$\sum Y^{2}=$ The Sum of Squares Writing Skill

$\left(\sum X\right)^{2}=$ The Squares of the sum of vocabulary mastery

$\left(\sum Y\right)^{2}=$ The squares of the sum writing skill

$\sum X Y=$ Total number of vocabulary mastery and writing skill

Based on the formula of Pearson Product Moment above, it was found that:

$\begin{array}{rlll}\mathrm{N} & =53 & \left(\sum X\right)^{2} & =3553225 \\ \sum X & =1885 & \left(\sum Y\right)^{2} & =940900 \\ \sum Y & =970 & \sum X Y & =41000 \\ \sum X^{2} & =73825 & \sum Y^{2} & =33050\end{array}$

Calculation:

$$
\begin{array}{r}
\text { Rxy }=\frac{(53 \times 41000)-(1885 \times 970)}{\sqrt{(53 \times 73825)}-3553255) \times(53 \times 33050-940900)} \\
=\frac{2173000-1828450}{\sqrt{359470 \times 810750}} \\
=\frac{344550}{\sqrt{291440302500}} \\
=\frac{344550}{539852,11} \\
=0,6382303479=0,638(\text { rounded })
\end{array}
$$

The result of formula Pearson Product Moment above showed that the correlation $\left(\mathrm{r}_{\mathrm{xy}}\right)$ between vocabulary mastery and writing skill is 0,638 .

\section{Testing Hypothesis}

Thehypothesis was tested by using Pearson Product Moment. The hypothesis tested by using $\mathrm{r}_{\text {table }}$ Pearson Product Moment coefficient is as follows:

\begin{tabular}{|c|c|c|}
\hline \multirow{2}{*}{$\mathrm{N}$} & \multicolumn{2}{|c|}{$\mathbf{R}_{\text {table }}$ of Pearson Product Moment Coefficient } \\
\cline { 2 - 3 } & \multicolumn{2}{|c|}{ Level of Significance } \\
\hline \multirow{3}{*}{53} & $\mathbf{5 \%}$ & $1 \%$ \\
\cline { 2 - 3 } & $\mathbf{0 , 2 7 9}$ & $\mathbf{0 . 3 6 1}$ \\
\hline
\end{tabular}


Based on the statistical calculation, it is found out that the hypothesis $\mathrm{H}_{0}$ is rejected since the $r_{x y} 0,68$ is higher than that on the table both at the level of significance of $5 \%$ and at the level of significance of $1 \%$.

It means that there is a significant correlation between vocabulary and writing skill. If someone has good vocabulary, he is also expected to have good writing skill.

Based on the $r_{\text {table }}$ of Pearson Product Moment Coefficient above, it can be seen that $r_{\text {table }}$ at the significance level 5\% is 0,279 and $r_{\text {table }}$ at the significance level $1 \%$ is 0,361 . If the $r_{\text {count }}$ is higher than $r_{\text {table }}$ it means that there is a significant correlation between vocabulary mastery and their writing skill. Since the $r_{\text {count }}$ $(0,638)$ is higher than $r_{\text {table }} 0,279$ ( significance level 5\%,0,361( significance level $1 \%)$. It can be concluded that there is a significant correlation between students' vocabulary mastery and writing skill. Therefore, $\mathrm{H}_{\mathrm{a}}$ ia accepted and $\mathrm{H}_{0}$ is rejected.

\section{Research Findings}

The writer should consult that there are some interpretation of the table. The interpretation presented as follows:

Table 7. The Interpretation Table of the Value
\begin{tabular}{|c|c|}
\hline The value of "r" & Interpretation \\
\hline $0,800-1,00$ & Very Strong \\
\hline $0,600-0,799$ & Strong \\
\hline $0,400-0,599$ & Moderate \\
\hline $0,200-0.399$ & Weak \\
\hline $0,000-0,199$ & Very Weak \\
\hline
\end{tabular}

After analyzing the data, the writer obtained the correlation coefficient from the formula Pearson Product Moment Coefficient is 0,638. After it is consulted to the interpretation table of significance level, the score is in $0,600-0,799$. It means that the correlation between vocabulary mastery and writing skill is strong. In the other words, if the teacher wants to improve his students' writing skill, he must improve the students' vocabulary first. It can also indicate that by mastering vocabulary someone will be able to write better than those who do not have vocabulary mastery. Vocabulary becomes something essential in language learning because without vocabulary there is little we can say both orally and in written form.

\section{CONCLUSIONS AND SUGGESTIONS Conclusion}

This research investigates the question of wheter there is significant correlation between vocabulary mastery and students' writing skill. There are two variables in this research: independent and dependent variable. The independent variable is vocabulary mastery, symbolized ' $\mathrm{X}$ ", and dependent variable is students' writing skill, symbolized "Y". research:

After analyzing the data, the writer drew the followoing conclusion of this

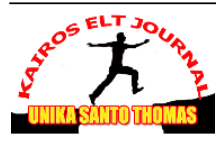


1. There is significant correlation between vocabulary mastery and writing skill in the tenth grade students of SMA Negeri 1 Kerajaan in the Academic Year of 2020/2021.

2. Futher, based on the data anaysis, it was found out that the students' vocabulary mastery was categorized into fair, while the students' writing skill was failed. It could be seen from the coefficient correlation of $r_{\text {count }}$ which is higher than $\mathrm{r}_{\text {table }}(0,638>0,279)$. It indicates that the correlation between students' vocabulary mastery. It indicates that the correlation between students' vocabulary mastery and writing skill is strong. In other words, if the students' vocabulary mastery is high it is automatically indicated that they have got high writing skill mastery. On the other hand, if they have got low vocabulary mastery, it is automatically indicated that they have got low in writing skill mastery and vice versa.

\section{Suggestions}

In the relation to the conclusion above, there are some suggestions that can be given by the writer to:

1. The English teacher

a. The English teachers are motivators and stimulators. They should motivate the students to increase their vocabulary in order to improve their writing skill.

b. The teachers are also expeted to be more active to find out the suitable teaching strategy in order to make the students can more enjoy in learning teching process in the class so that the students can get the point of the teaching learning process easily.

c. Teacher should make and provide exercise about vocabulary continously in order to make the students master in vocabulary.

2. The Students

a. Students should improve their vocabulary mastery in order to make them easier in writing, so that they can write in English easily.

b. the students must be active and always practice to write.

c. The students should pay more attention to the lesson explained by the teacher, especially in vocabulary and writing during the learning teaching process.

d. The more vocabulary you master, the easier you can write.

3. Others researchers

Others researchers, who are interested in conducting the similar studies, can make the result of this study as their reference. The result of this study hopefully provides ther researchers the valuable information on the correlation between vocabulary mastery and writing skill. Perhaps, others can conduct similar research with different topic of correlation, for instance grammar and writing skill or vocabulary and reading comprehension.

\section{BIBILOGRAPHY}

Arikunto, S. 2002. Prosedur Penelitian. Jakarta: Rineka Cipta. 
Azizah, Y. 2017. The Correlation Between Students' Vocabulary Mastery and Their Writing Sudirman 1

Ability in Descriptive Text (A Study for the Seventh Grade of SMP Islam Bancak Semarang District) in Academic Year 2016/2017. A Sarjana's Thesis, Teacher

Training and Education Faculty: Islamic Studies (IAIN) Salatiga.

Cameron, L. 2001. Teaching Language for Young Learners. Cambridge: Cambridge

University Press.

Flower, J. 2000. Build Your Business Vocabulary. Boston: Thomson Heintei Publisher.

Fraenkel, J. R and Norman, E. W. 2015. How to Design and Evaluate Research in Education.

New York: McGraw Hill.

Harmer, J. 2001. The Practice of English Language Teaching(Third Edition). London:

Longman.

London: 2002. The Practice of English Language Teaching(Third Edition). Longman. 2004. How to Teach Writing. Essex: Pearson Education. 2007. The Practice of English Language Teaching. Third Edition.

London: Longman.

Hatch, E \& Brown, C. 1995. Vocabulary, Semantics and Language Education. Cambridge: Cambridge University.

Hiebert, E \& Kamil, M. 2005. Teaching and Learni Vocabulary Perspective and Persistence

Issues. London: Lawrence Erbium Associates Publisher.

Kumar, R. 2005. Research Methodology A Step - by - Step Guide for Beginners(Secnd

Edition). Singapore: Pearson Education.

Langan. 1993. Vocabulary, Semantics and Language Education. Cambridge: Cambridge University Press. 
2005. College Writing Skill. New York: McGraw Hill.

Nunan, D. 1998. Language Teaching Methodology. Sydney: Macquarie University Press. Company.

2003. Practical English Language Teaching. Singapore: McGraw Hill 2012. Language Teaching Methodology. Cambridge: Cambridge University Press.

Nurgiyantoro, B. 2001. Penilaian Pembelajaran Bahasa Berbasis Kompetensi. Yogyakarta.

BFFE Yogyakarta.

Olinghouse, N. G and Wilson, J. 2012. The Relationship Between Vocabulary and Writing Quality in Three Genres. Reading and Writing,26(1),45-65.

Sariatun. 2010.The Correlation Between English Vocabulary Maatery and Writing Ability of

the Eighth Grade Students of SMPIT Rahmatan Lil Alamin Babadan Ponorogo in

Academic Year 2009/2010.A Sarjana's Thesis in state Islamic College of Ponorogo.

Starkey,L. 2004. How to Write Great Essays. New York: Learning Express.

Thornbury, S. 2002. How to Teach Vocabulary. London. Pearson Educational. 